\title{
Comparison of Damping Effects of Two Types of Graphite Cast Iron
}

Petra Kováčiková, Andrej Dubec, Ján Vavro

Faculty of Industrial Technologies in Púchov, Alexander Dubček University of Trenčín. I. Krasku 491/30, 02001 Púchov. Slovakia. E-mail: petra.kovacikova@fpt.tnuni.sk

This paper deals with the evaluation of the graphite cast iron structure and change of the dynamic behavior dependent on the graphite shape. Structural analysis is focused on the study of cast iron with flake and globular graphite. These two materials have a considerable application in manufacturing due to its specific mechanical and physical properties. The production of gray cast iron is less demanding in terms of the technological process and the quality of the raw materials compared to ductile cast iron but this material is the best for the production of castings. Compared with cast steels are these graphite castings less susceptible to the notch effects of fatigue stress and have a higher value of damping. Internal damping occurs in the structure of the material and can be caused by its imperfection. Computational measurement of eigenshapes and eigenfrequencies was performed using modal analysis in the SolidWorks software environment.

Keywords: ductile cast iron, gray iron, flake graphite, finite element method

\section{Introduction}

Currently, there is produced more ductile cast iron than malleable cast iron or cast steel. Many castings made of gray cast iron, malleable cast iron, cast steel, steel forgings and installed components have been successfully converted into ductile iron castings. Compared to the production of other graphite cast iron, the production of gray cast iron is not so difficult in terms of technological procedures and relatively low price. The spheroidal shape of the graphite does not cause suchtension concentration as flake graphite does. Flake graphite is a bonded and branched formation that acts positivelyon foundry properties [1]. Compressive strength and flexural strength are several times greater than tensile strength, but due to graphite excreted in flakes, they are positively manifested by increased attenuationcapability. In terms of strength, gray cast iron is mainly used for highly stressed castings of machinery parts, for heavy machine tool stands, fittings,

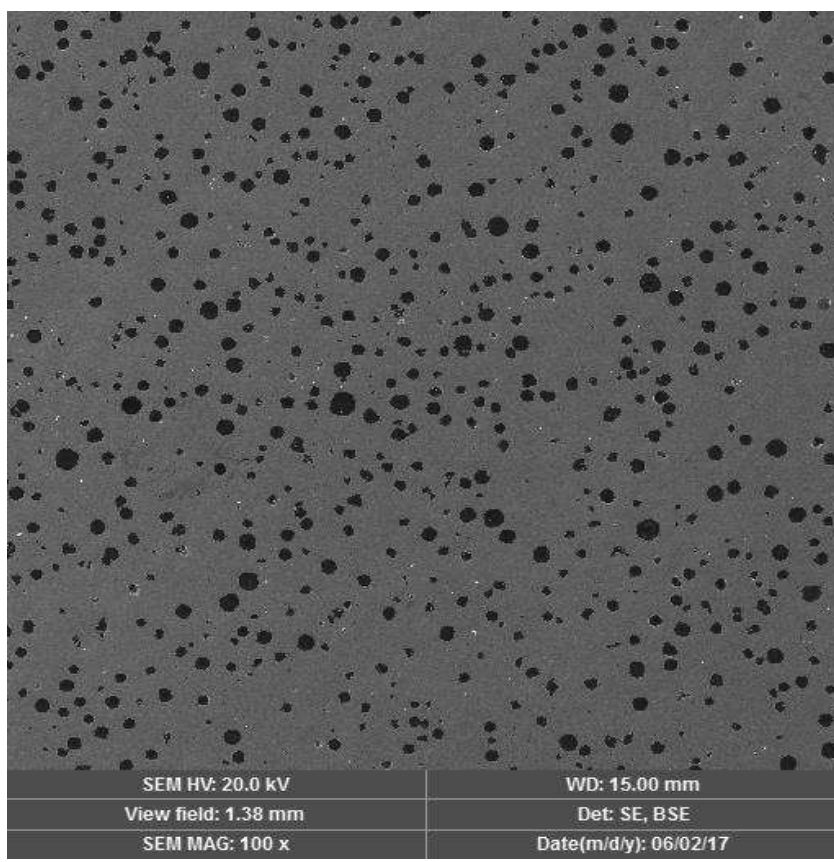

gear boxes and others [2]. Increasing demands are emphasized on mechanical structures and machinery in operation. Their performance and operating speed increase, resulting in undesirable vibrations [3]. This undesirable feature and exceeding the critical vibration limits in the machinerynegatively affects their durability, reliability and can cause degradation of machinery or components [4].

\section{Material characteristics}

For assessment of this type of experimental materials, the standard STN 420461 is appropriate, which describes the material characteristics of graphite cast iron, made as sections in non-etched as well as etched condition. The analysis of prepared samples was carried out on thermoemission scanning electron microscope Vega 3 Tescan. The graphite particles are mostly uniformly distributed in the ductile cast iron (Fig. 1) with a regular grain shape (Fig. 2).

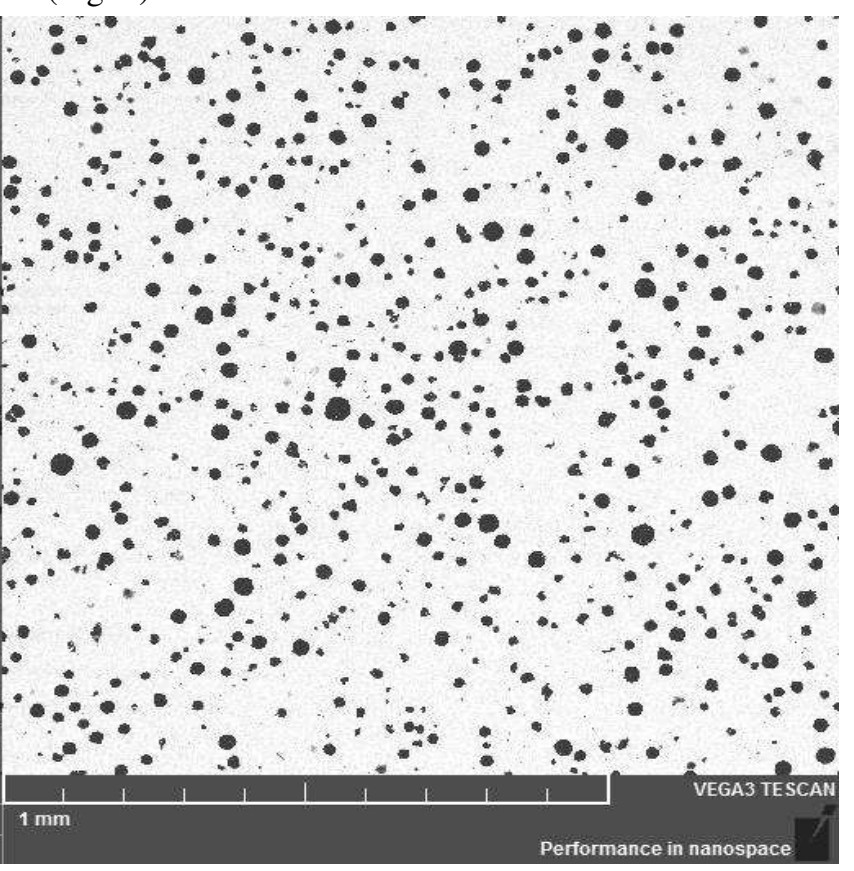

Fig. 1 Distribution of graphitic particles in a metal matrix of ductile iron 


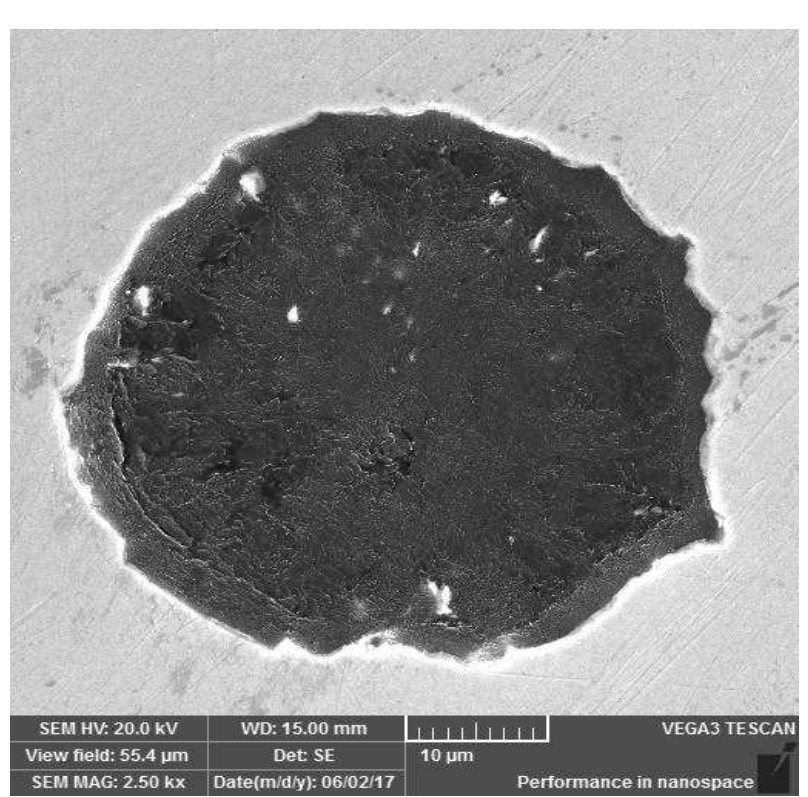

Fig. 2 Cross section of graphite particle

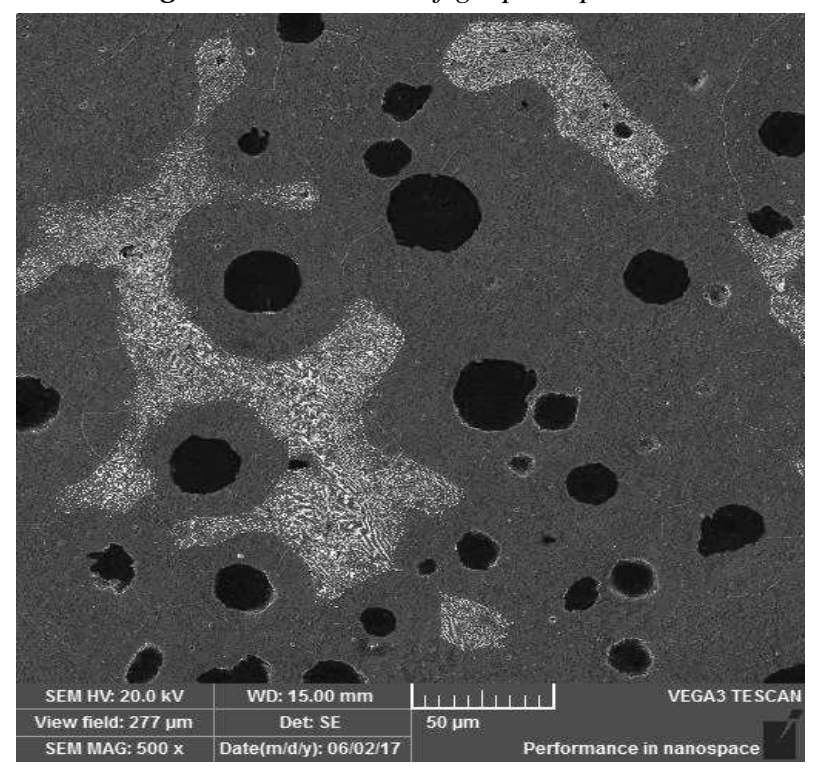

Fig. 3 Ferritic-pearlitic matrix, Nital

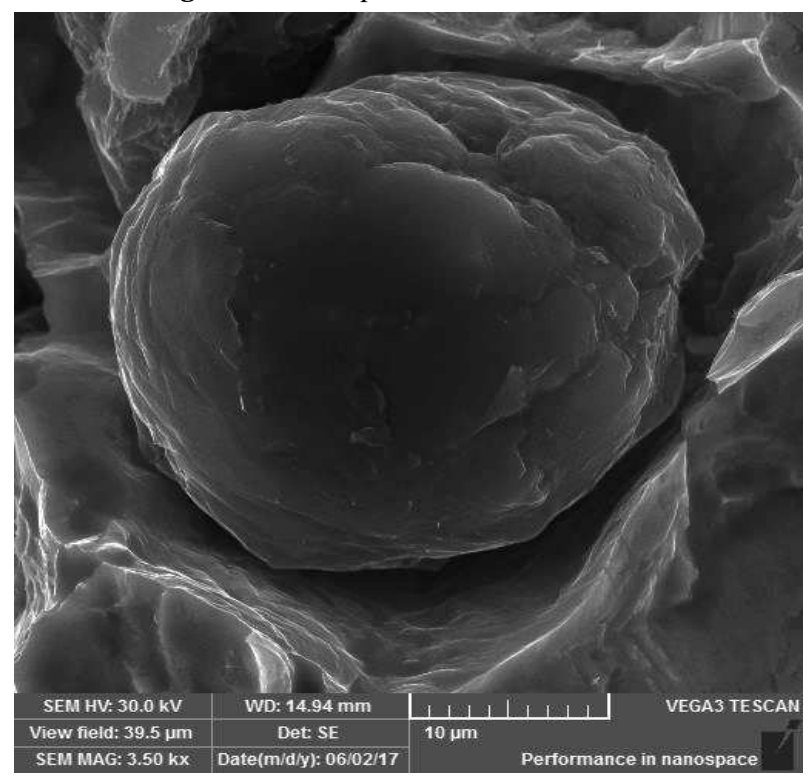

Fig. 4 Detail of globular graphite

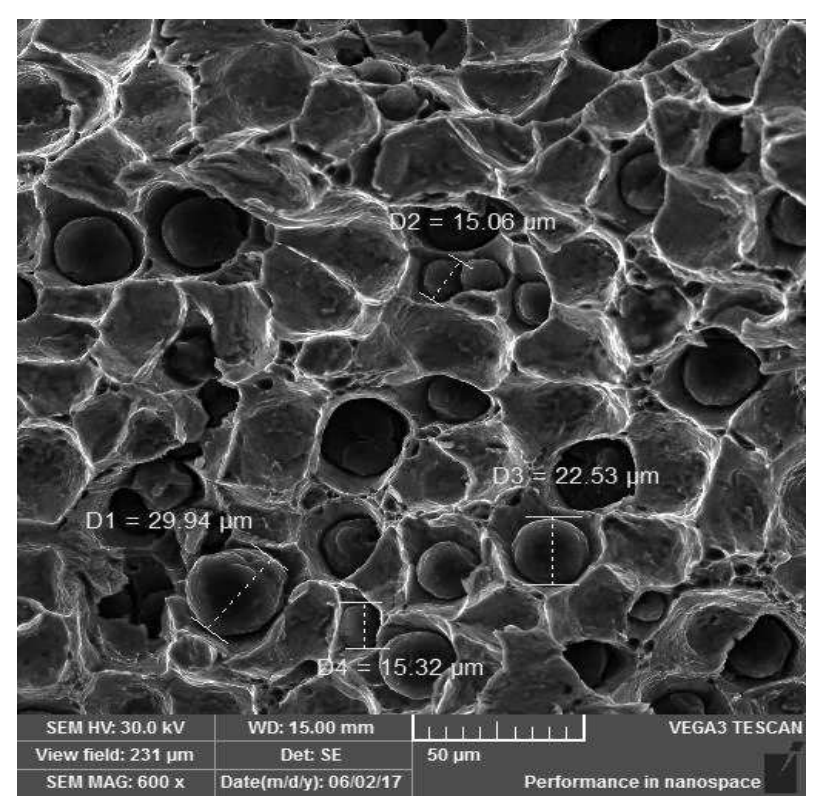

Fig. 5 Graphite particle size (laboratory fracture)

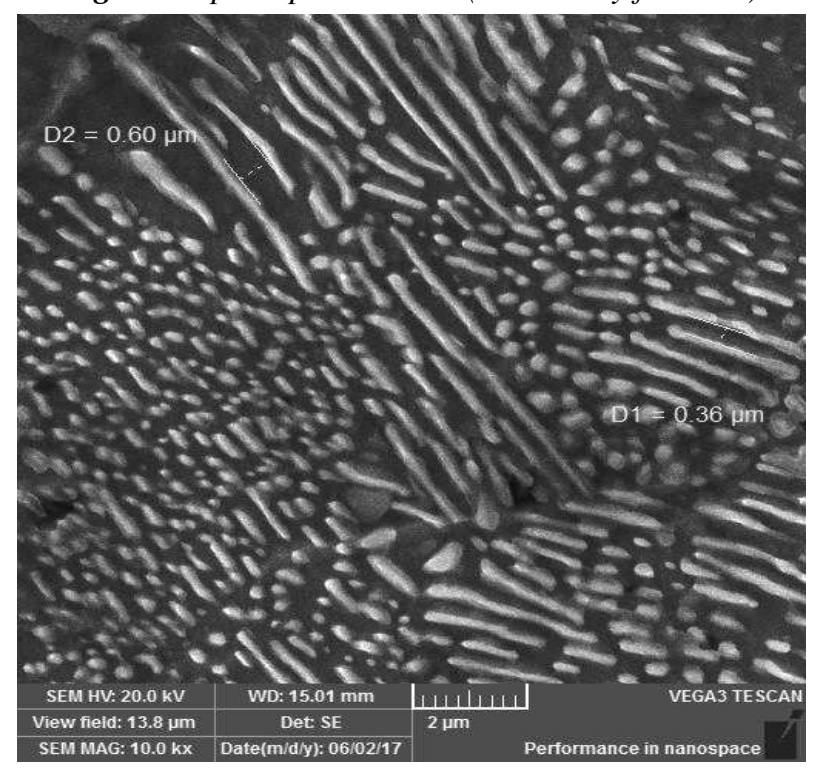

Fig. 6 Dispersion of pearlite in ductile cast iron, Nital

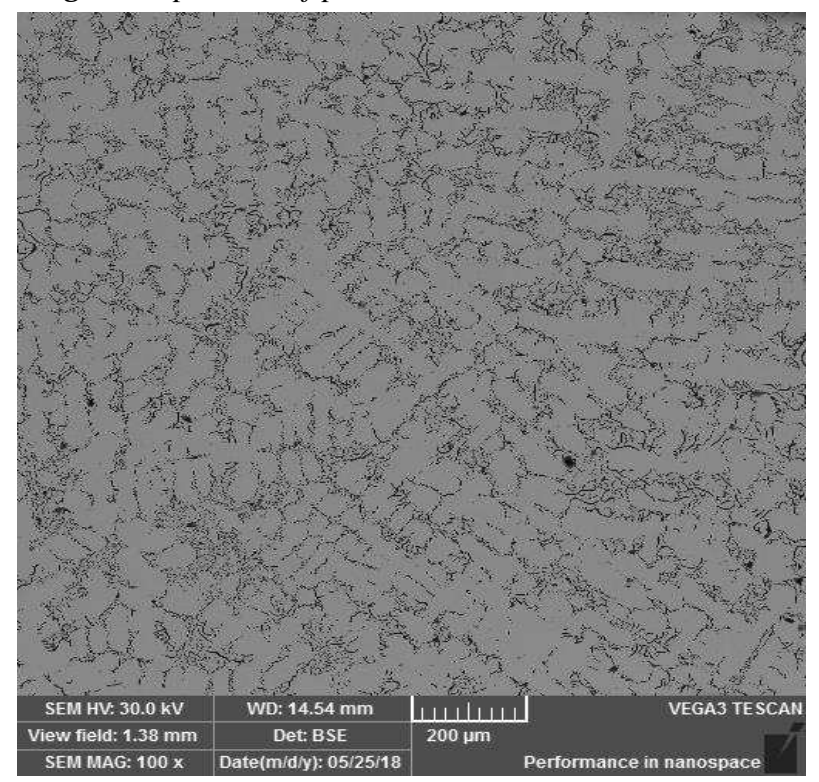

Fig. 7 Distribution of graphite particles 
This type of graphite may be obtained by modification, while the amount of globular graphite in cast iron structure is indicated as $[3,5]$. The microstructure of the metal matrix, filling the space between the graphite particles, is mainly composed of ferrite with $2 \%$ content of pearlite (Fig. 3). The size of globular graphite is in the range of $15 \mu \mathrm{m}-30 \mu \mathrm{m}$ (Fig. 4, 5). Due to its shape, this type of graphite particles does not cause a higher tension concentration in the metal matrix as in the case of flake shape of graphite. The distance of cementite lamellae in the pearlite structure, characterized as pearlite dispersion, ranges from $0.3 \mu \mathrm{m}$ to $0.6 \mu \mathrm{m}$ (Fig. 6).

In practice, ductile cast iron is used for the production of machinery bases, engine cylinders and highly stressed components. Due to its good mechanical properties and exceptional attenuationcapability, this type of graphite cast iron is one of the high-quality materials with extended use.Another analyzed material is gray cast iron. Graphite particles are dispersed interdendritically and undirectionally in the metal matrix (Fig. 7). The graphite is excreted in the cast iron in the form of flakes with characteristic decrease in their thickness from the center of flake to its edge (Fig. 8,9). The size of the graphite particles ranges from $30 \mu \mathrm{m}$ to $60 \mu \mathrm{m}$, corresponding to the $6^{\text {th }}$ grade according to the standard mentioned above (Fig. 10). This dimension represents the distance determined by section of branches of graphite formations and does not correspond to the real length of graphite flakes. The metal matrix of the analyzed gray cast iron is composed of lamellar pearlite with $98 \%$ content, which also corresponds to the absence of a visible occurrence of ferritic structure (Fig. 11). The high proportion of pearlite may be due to the higher speed of cooling the cast iron, as evidenced by the fine-grain structure [6]. The average lamellar pearlite dispersion is $131.63 \mu \mathrm{m}$ (Fig. 12).

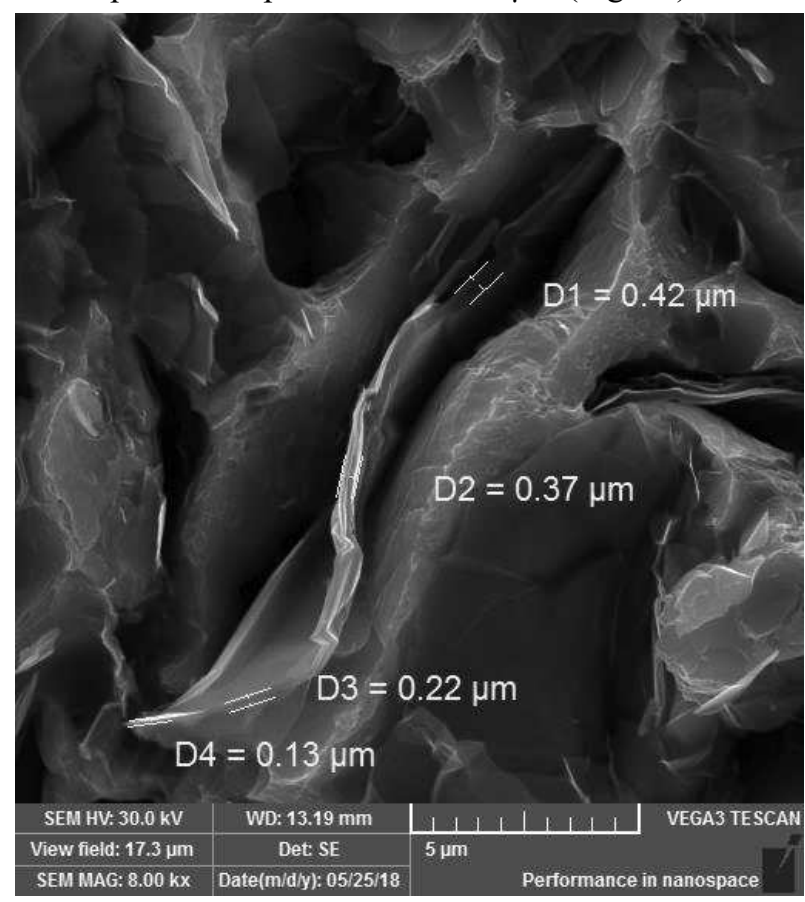

Fig. 8 The shape of flake graphite

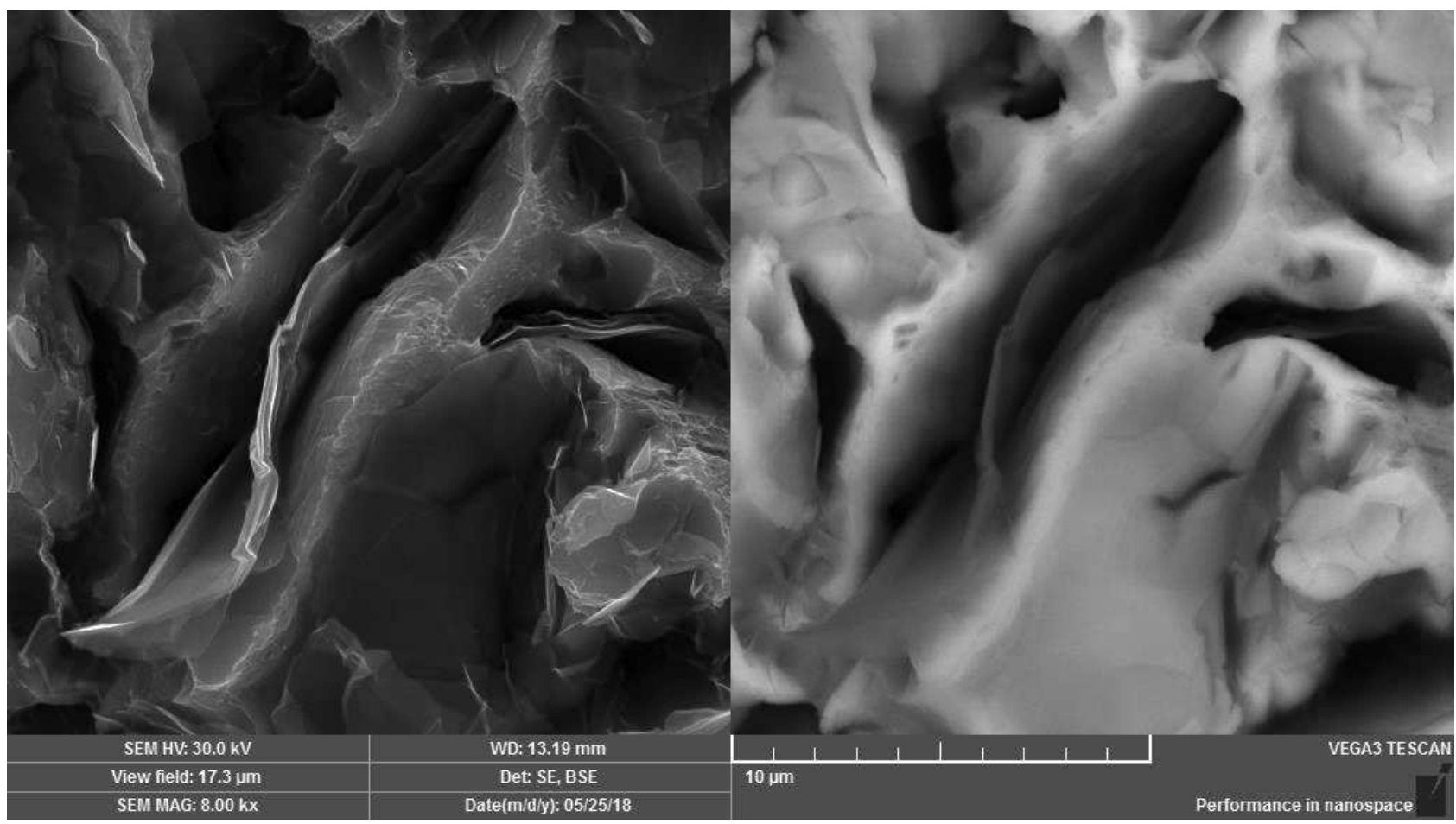

Fig. 9 Flake graphite on fracture surfaces

Smaller dispersion is associated with increasing values of strength and hardness of gray cast iron, at the expense of decrease in ductile properties [7]. Such a structure found throughout the casting may also cause an increase in wear resistance and an improvement in corrosion resistance [8]. Non-metallic inclusions, especially titanium carbonitrides, were observed in the gray cast iron structure (Fig. 13), their occurrence was only rare and they reached a size of up to $5 \mu \mathrm{m}$. 


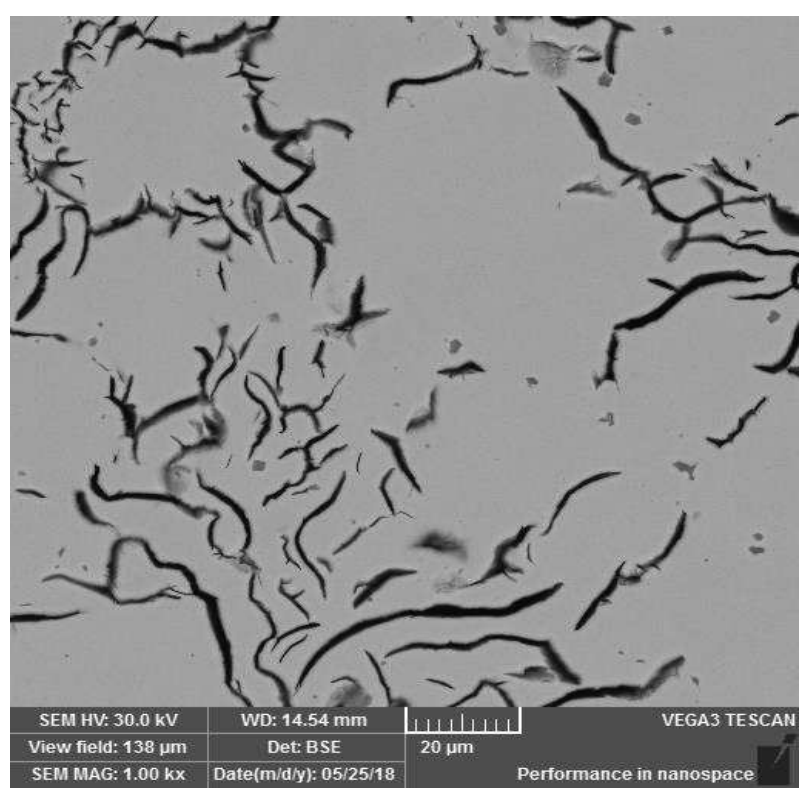

Fig. 10 Size of flake graphite particles

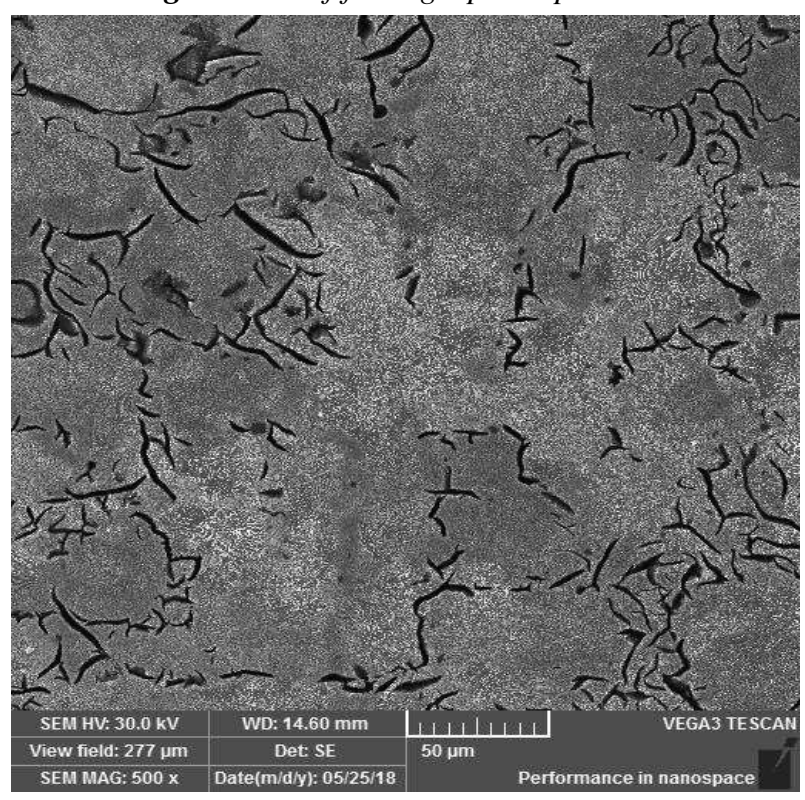

Fig. 11 Lamellar pearlite, Nital

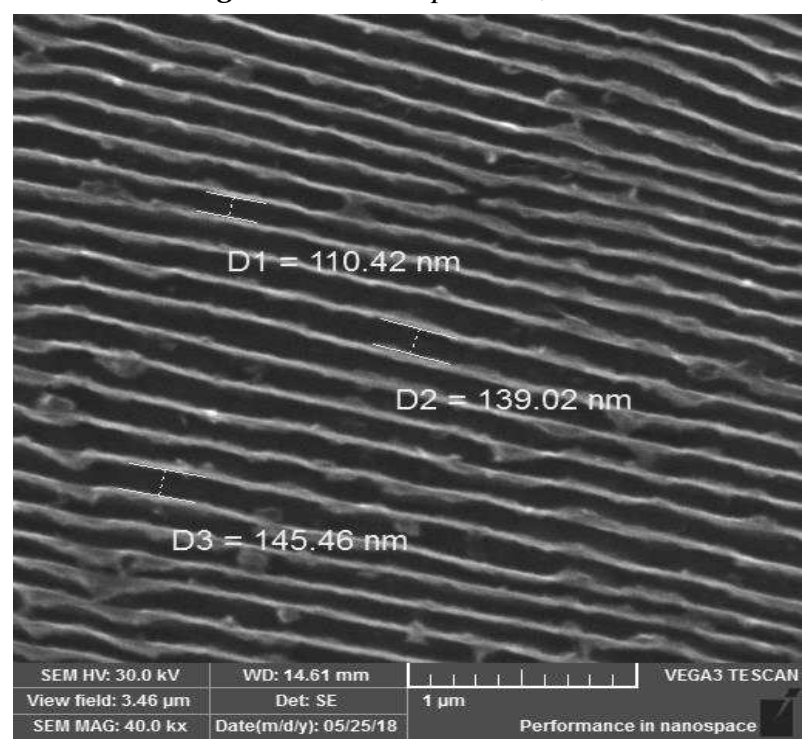

Fig. 12 Pearlite dispersion, Nital

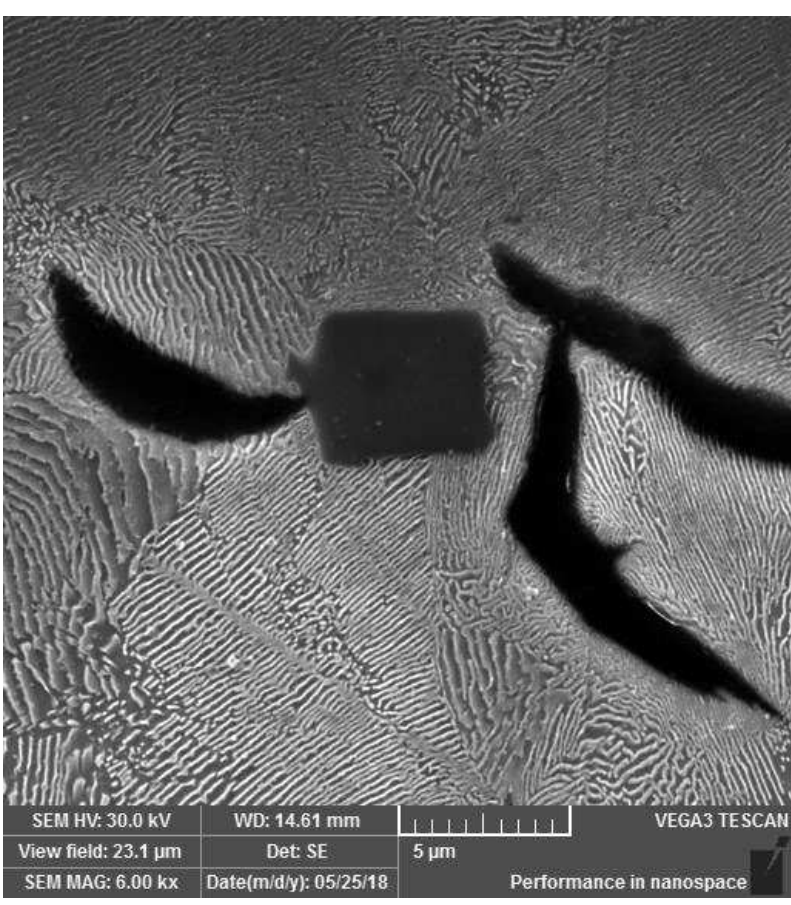

Fig. 13 Titanium Carbonitride, Nital

\section{Modal analysis}

An essential factor in the oscillation of structural materials is their own shape, frequency and damping. The modal test is applied to the tested component or structure in order to obtain a mathematical description of their dynamic behavior using modes $[9,10]$. Modal analysis and the associated determination of basic dynamic characteristics is a fundamental step in dynamic calculations. Using the FEM, there is used a discrete system that is characterized by discrete mass points and their corresponding rigidity. The FEM model (Fig. 14) is used to verify the computational dynamic behavior and real behavior observed in practice [11]. Based on the results obtained, the model is modified to reach the most accurate results. Tuning the FEM model is possible by changing material parameters, changing the type of elements or adding damping [9]. The analysis of the sample model of the homogeneous beam [12] strength and damping properties, was carried out using the finite element method in the software environment SolidWorks (Tab. 1).

Input material parameters for cast iron with graphite spheroidal shape and cast iron with graphite flake shape were defined with respect to the elastic modulus $\mathrm{E}$ being closely linked to the structure (strength, hardness). The higher the strength and hardness, the greater the elastic modulus [13].

Tab. 1 The first 5 own frequencies

\begin{tabular}{|c|c|c|}
\hline mode & $\begin{array}{c}\text { frequency } \\
\text { (ductile cast } \\
\text { iron) }\end{array}$ & $\begin{array}{c}\text { frequency } \\
\text { (grey iron) }\end{array}$ \\
\hline 1 & $77.65 \mathrm{~Hz}$ & $51.31 \mathrm{~Hz}$ \\
\hline 2 & $486.92 \mathrm{~Hz}$ & $321.24 \mathrm{~Hz}$ \\
\hline 3 & $511.58 \mathrm{~Hz}$ & $336.69 \mathrm{~Hz}$ \\
\hline 4 & $1303.76 \mathrm{~Hz}$ & $898.66 \mathrm{~Hz}$ \\
\hline 5 & $1366.97 \mathrm{~Hz}$ & $1205.75 \mathrm{~Hz}$ \\
\hline
\end{tabular}


Fig. 14 Computational model of homogeneous beam.

\section{Conclusion}

Before introducing into operation, it is necessary to know the particular material also in terms of structure, because the internal damping occurs in the material structure and may be caused by its imperfection. Flake graphite is a branched formation and its compressive strength and flexural strength are several times greater than tensile strength, but due to the graphite excreted in the flakes, it positively manifests itself by increased attenuationcapability. All types of cast iron have the capability to absorb noise and vibration. Damping capability of ductile cast iron with graphite spheroidal shape is higher than damping capability of steel, but is lower than damping capability of gray cast iron with flake graphite shape. Designing 3D models accelerates the complete manufacturing process from design to final product. In practice, this system is an integral part of many companies for performance, reliability and continuous development. Manufacturing requires more and more demands on the operation of the machinery parts, and the undesirable effects, which result in increased vibration and noise, negatively affect their functionality. Therefore, we are looking for possibilities to prevent them in the way so that we do not limit their technical parameters and efficiency of operation by the right choice of material. Nowadays, graphite cast iron, especially gray cast iron and spheroidal graphite cast iron, prevail on the market as material for castings, as evidenced by the production volume. Modal analysis combines signal processing and computer technology interaction, theory of mechanics, vibration, acoustics, applied mathematics and engineering prediction. It is conducted to compare the dynamic behavior of a structure from a computational model to a model obtained experimentally.

\section{Acknowledgement}

This paper deal was supported by the Slovak Grant Agency KEGA 007TnUAD-4/2017, VEGA grant No. 1/0649/17, VEGA grant No. 1/0589/17. The work was supported by the project "Center for quality testing and diagnostics of materials - CEDITEK", ITMS code 26210120046 relating to the Operational Program Research and project, Advancement and support of $R \& D$ for "Centre for diagnostics and quality testing of materials"in the domains of the RIS3 SK specialization", code NFP313010W442.

\section{References}

[1] EPERJEŠI, Š., MATVIJA, M., BARTOŠOVÁ, M., FECKO, D., PRIBULOVÁ, A. (2017). Effect of Heat Treatment Conditions on Micro Structure of Cast Iron, Manufacturing Technology, No 1, Vol. 17, (2017), ISSN 1213-2489, p. 29-33.

[2] SKOČOVSKÝ, P., PODRÁBSKÝ, T. (2005). Graphitic cast iron. ŽU v EDIS, Žilina, 2005, 168 s. ISBN 80-8070-390-6

[3] HANDRÍK M., JAKUBOVIČOVÁ L., KOPAS P., SÁGA M. (2010). Analysis of microplastic areas near graphite particles of nodular cast iron loading bellow yield stress, Metalurgija (Metalurgy), No. 2, Vol. 49, (2010), p. 263 - 267, ISSN0543-5846.

[4] VAVRO, J. (2013). Numerical analysis of voltage states of graphite cast iron structures. Issue I., Žilina, , p 76. ISBN 978-80-8075-614-7.

[5] NOVÝ, F., KOPAS, P., BOKUVKA, O., SAVIN, A. (2016). Fatigue Durability of Ductile Iron in Very-High-Cycle Region, Manufacturing Technology, No. 2, Vol. 16, (2016), ISSN 1213-2489, p 406-410.

[6] SKOČOVSKÝ, P., MATEJKA, M. (1994). Microstructure of cast iron-metallographic manual. Fompex Trenčín-ES VŠDS,

[7] SKOČOVSKÝ, P.,ŠIMAN, I. (1989). Structural analysis of cast iron. ALFA Bratislava.

[8] SKOČOVSKÝ, P., PODRÁBSKÝ, T. (2005). Graphitic cast iron. ŽU v EDIS, Žilina, 2005, 168 s. ISBN 80-8070-390-6

[9] BILOŠOVÁ, ALENA. (2006). Experimental Modal Analysis. VŠB - Technical University of Ostrava, p. 104.

[10] BITTNER, V., TUČEK, R., PANSKÁ, Š., SVOBODA, M., JELEN, K.: Using the fourier transform in the analysis of vibration load tests of heterogeneous mechanical systems, Manufacturing Technology, Vol. 17, no. 6 (2017), ISSN: 1213-2489

[11] EWINS, D.J. (1988). Modal testing: Theory and Practice. Gilliard, Great Yarmouth, p. 269. ISBN 0-86380-017-3.

[12] Standart test method for measuring vibrationdamping properties of materials. Code ASTM E 756-04, ASTM International, 2004

[13] KOPAS P., HANDRIK M., JAKUBOVIČOVÁ L., SÁGA M. (2010). Computational simulations of stress distribution in surrounding of graphite particles. Machine Dynamics Research, 2010, No. 3, Vol. 34, p. 115 - 123, ISSN 2080-9948. 